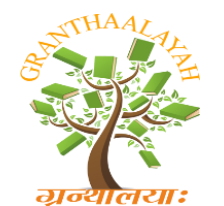

INTERNATIONAL JOURNAL OF RESEARCH GRANTHAALAYAH

A knowledge Repository

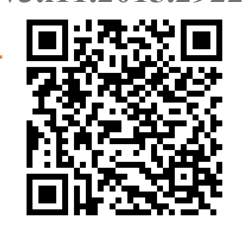

Management

\title{
CONSUMERS' PREFERENCE ANALYSIS TOWARDS ENGLISH COURSES IN BANDUNG (A STUDY ON HIGH-SCHOOL STUDENTS IN BANDUNG)
}

\author{
Peggy Hariwan ${ }^{1}$, Diah Agung Esfandari ${ }^{2}$, Rhea Pagita $S^{3}$ \\ ${ }^{1,2,3}$ Faculty of Communication and Business, Telkom University, INDONESIA
}

\begin{abstract}
This study examines the consumer preferences of English Course in Bandung. The object of this study are English courses in Bandung with the attributes of teaching methods, location, number of students, and the type of program. This study examines the attributes that the most considered by consumers in choosing an English Course in Bandung and also can provide a recommendation for an English Course in Bandung related to offering the course as desired by the consumer. This type of research used in this study is a descriptive study using quantitative methods. The population in this study are students in senior high school in Bandung with samples taken 100 respondents using purposive sampling technique. Data analysis techniques used in this study is conjoint analysis to obtain a utility score and importance score that of the scores can be deduced about what the most is considered by consumer in selecting a product. The results from this study were obtained importance score from level which affecting consumer preferences on an English Course in Bandung. The highest attribute is the type of program (50.65\%) with a level of Conversation Class (0.162). The second is the attribute of the number of students (23.49\%) with a rate of 10-20 people per class (0.092). The third is the location attribute with a level close to the school (0.054). Last attribute is a teaching method (11.26\%) with expert faculty level (0.051).
\end{abstract}

Keywords:

Conjoint analysis, Consumer behavior, Consumer preference, Senior high school students.

Cite This Article: Peggy Hariwan, Diah Agung Esfandari, and Rhea Pagita S, "CONSUMERS' PREFERENCE ANALYSIS TOWARDS ENGLISH COURSES IN BANDUNG (A STUDY ON HIGH-SCHOOL STUDENTS IN BANDUNG)" International Journal of Research Granthaalayah, Vol. 3, No. 11(2015): 122-132.

\section{INTRODUCTION}

Along with the development of economy and technology in the world, borders between countries seem to be of no consequence. Especially nowadays, where people from almost every country work together in many areas. English is the language that originated from the United Kingdom and is the primary language of the United Kingdom, the United States and other Commonwealth 
countries (Schneider, 2011). Therefore, English is currently an international language because it is used in almost every country in the world, and to the Indonesians, it has a great importance in the era of globalization as it helps to compete. There are many ways in order to learn the language, one of which is to follow courses that are tailored to the customers' needs. As the need to learn English increases, so does the competition between one courses to another.

Table 1: NUMBER OF COURSES IN INDONESIA
\begin{tabular}{|l|l|l|}
\hline No & Types of Courses & Total \\
\hline 1. & Computer & 5717 \\
\hline 2. & English & 4424 \\
\hline
\end{tabular}

Based on the data above, there are many types of courses in Indonesia. English courses is the second highest after Computer lessons in which it proves that people's interest to hone their language proficiency is also high.

Table 2: NUMBER OF COURSES IN WEST JAVA

\begin{tabular}{|l|l|l|}
\hline No & Type of Courses & Total \\
\hline 1. & Computer & 658 \\
\hline 2. & English & 624 \\
\hline
\end{tabular}

Source: Directorate General of Training and Courses Early Childhood Education (Non-Formal and Informal) Ministry of Education and Culture.

The data shows that there are 624 English courses in the provie of West Java. In order to save time and costs, the authors have decided to focus their research in Bandung where there are 15 registered English courses.

To increase the effectiveness and efficiency of this research, as well as to save time, expense, and effort the authors chose several English courses that are well-known in Bandung. Those places were chosen based on the interviews of 30 people from several high-schools and/or high-school's level courses.

According to the consumer behavior survey's results, the reason high-schools students choose to take the English course is because the lesson delivered at their schools are not effective enough. However, the results also show that those high-school students are not loyal to only one English course. The reason is that they want to try as many English courses as they can, until they find the right one and/or the one that correspond to their needs and requirements. One of the factors that contribute to such decision is the quality of the English course. However, when such a place does exist but the location is too far from where they live, those high-school students will choose another English course that is nearer. Thus, it can be concluded that high-schools students are still unfaithful to one English course as they are still searching for the one that correspond to their needs. 
Based on the consumer behavior survey's results, one of the considerations in deciding the English course is the stimulating teaching method. The aspect that mostly affects high-school students in selecting the English course, is themselves, in which the average students can make their own decisions in choosing the right place. There are three types of criterion that high-schools students consider when choosing an English course: 1. Teaching - method and/or teachers, 2. Reachable location, and 3.Various (available) programs. Based on the consumer behavior survey's results, the English courses that high-school students favor are English First, LBPP LIA, The British Institute, and ILP.

The favored English courses, above, will be used by the authors as references for this research. The authors will also choose high-school students as population as most of them are capable enough in choosing their own English courses, without their parents' interference. According to Kolawole (1998:81) "There are many obstacles for people in learning English such as the insufficient time, ineffective learning-method, and scarcity of adequate English teachers." In addition, the quality and skill that the schools offer are inadequate, eventhough, English lessons are being taught frequently about 4-5 times a week (source: education curriculum).

As time passes and development expands, high-school students would want a better quality of services from the English courses that they have chosen. According to Kotler and Keller (2009:14), a company will be successful if it provides value and satisfaction to the buyer or consumer market. As consumers choose different offerings based on their greatest value. Consequently, based on the consumers' demand it is only logical if the English courses prepare themselves and find the best strategy to enhance consumer's comfort and satisfaction.

As a result, based on the information described above, the purpose of this research is to find out high-school students' preferences towards the English courses in Bandung, and what attributes which is most important in selecting the right place.

\section{THEORETICAL GROUNDWORK}

According Thamrin and Francis (2012:22), marketing is a social and managerial process in which individuals and groups obtain their needs and desires by creating, offering, and exchange products of value to each other. According to Kotler (2011:150), the service or services is any act or acts that can be offered by one party to another, that is essentially intangible (physical intangible) and does not produce ownership of something. According to Nitisusastro (2012:33) consumer behavior is the stages of steps taken and carried out by a person/individual or groups of people in order to meet your needs and desires. Thamrin and Francis (2012:129) in their book shows a 'model stages' of the consumer's purchase process through five stages: introduction to the issue, information retrieval, evaluation of alternative, purchasing decisions, and consumer's behavior after purchased. According to Kotler and Keller (2009:210) there are several stages that consumers have to go through in order to achieve their satisfaction towards a product. Below are the stages: 


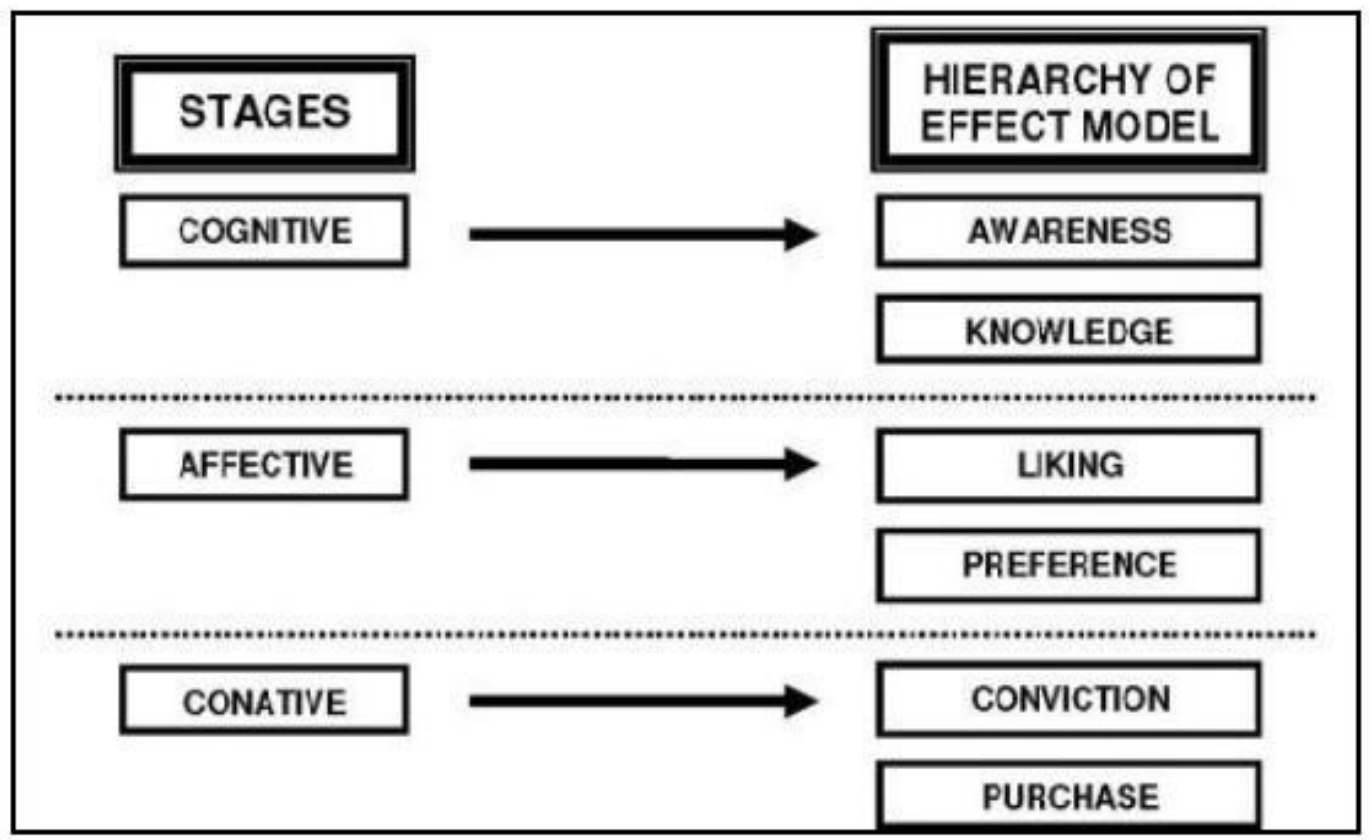

Source: Kotler and Keller (2009)

The preference stage in which the consumer feels towards a product, is the beginning of consumer's loyalty towards that particular product. As a result, companies need to learn on how to create or built preference in potential consumers. According to Kotler and Keller (2009:294), there are three patterns of preference that can be formed:

1) Homogenous preference in which consumers have similar preferences.

2) Dispersed preference in which consumers have different preferences.

3) Group preference in which the market shows different groups with different preferences.

By understanding consumers' preferences, the company can design the right strategy to respond to consumers' expectations and make it as differentiation strategy from other companies and/or competitors.

\subsection{THOUGHT OF FRAMEWORK AND HYPOTHESIS}

The purpose of this research is to know the consumers' preferences in choosing the place for English Courses in Bandung using four attributes, and to know the level of importance of each attributes. The consumers' preferences attribute is outlined in Picture 2. 


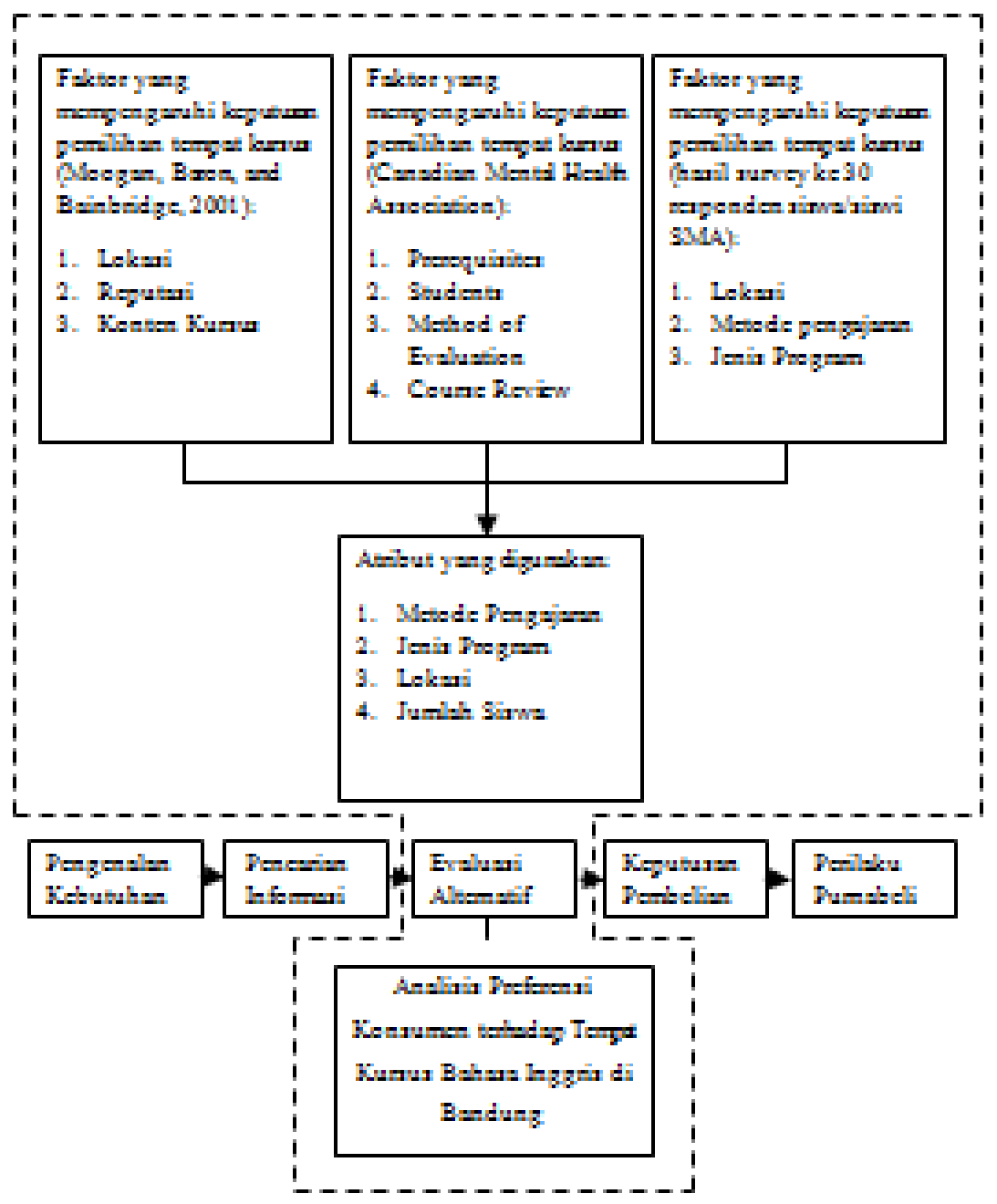

\subsection{SAMPLE}

Picture 2: Thought of Framework

Non-probability sampling is used as technique sampling's retrieval, since it does not give the same opportunities to any of its elements or members of the sample population. Whereas purposive sampling is used to determine the sum of respondents (or samples). The sample used in this research is 100 respondents, since the least amount of samples is 96,04 respondents. The number of these respondents will be taken from high-school students in Bandung.

\section{RESULT AND DISCUSSION}

\subsection{CONJOINT ANALYSIS}

The following are the conjoint analysis results concerning consumers' preferences in choosing the place for English courses in Bandung, and the level of consumers' needs towards the English course itself. A more detailed data can be seen in the following Table 3: 
Table 3: Conjoint Analysis Results

Hasil Analisis Konjoin Tempat Kursus Bahasa Inggris

\begin{tabular}{|c|c|c|c|}
\hline Atribut & Taraf & Utilitas & Importance \\
\hline \multirow{3}{*}{$\begin{array}{l}\text { Metode } \\
\text { Pengajaran }\end{array}$} & Pengajar Ahli & .051 & \multirow{3}{*}{$11.26 \%$} \\
\hline & $50 \%$ pengajar ahli $-50 \%$ native & -.045 & \\
\hline & $100 \%$ native (pengajar asing) & -.007 & \\
\hline \multirow{3}{*}{ Lolsasi } & Di Pusat Kota & .016 & \multirow{3}{*}{$14.60 \%$} \\
\hline & Delkat dengan Sekolah & .054 & \\
\hline & Di Pinggiran Kota & -.070 & \\
\hline \multirow{3}{*}{ Jumlah Siswa } & $<10$ orang per kelas & .016 & \multirow{3}{*}{$23.49 \%$} \\
\hline & 10-20 orang per kelas & .092 & \\
\hline & $>20$ orang per kelas & -.108 & \\
\hline \multirow{3}{*}{ Jenis Program } & Kelas Reguler & .107 & \multirow{3}{*}{$50.65 \%$} \\
\hline & Conversation Class & .162 & \\
\hline & Kelas Persiapan Tes & -.269 & \\
\hline
\end{tabular}

Table 3 shows the conjoint analysis results concerning consumers' preferences in choosing the place for English courses in Bandung. The results of utility and importance are acquired through data processing and the help of SPSS 21.00. In this research, there are four attributes: teaching methods, location, number of students, and program type. Each attributes have sub-level or different degrees. The value of utility in each attributes differ between one another. Below (Picture 3) will explain the value of utility on each attributes.

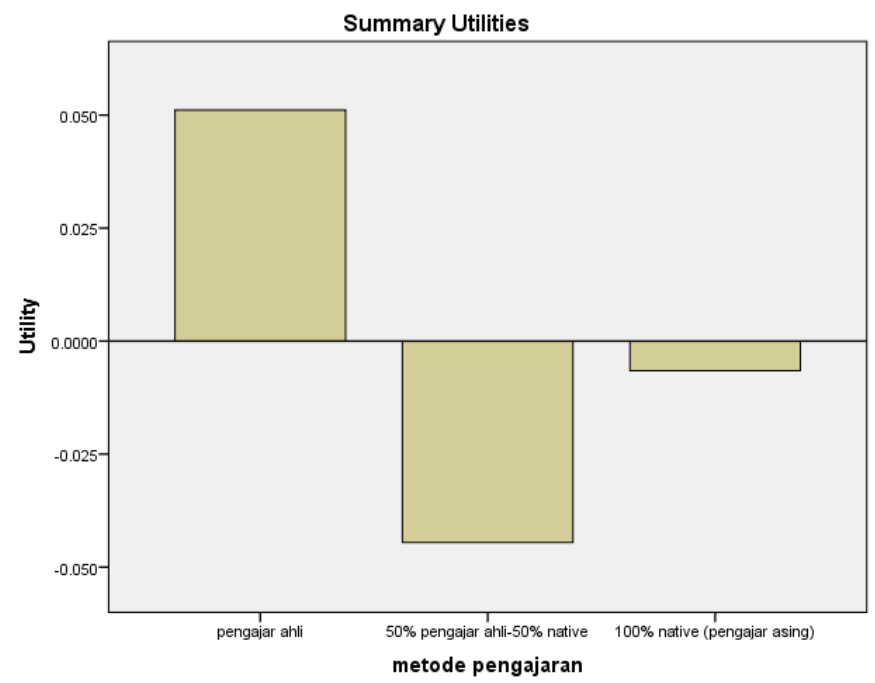

Picture 3: The Value of Teaching Method's Attribute Utility 
From the picture above, the utility's value of the teaching method is 0.051 for expert faculty, in which if the English course has 50\%-native speakers and 50\% local teachers than its utility's value is -0.045 while if the English course has $100 \%$ native speakers as teachers, than its utility's value is -0.007 .

Based on the data above and 100 respondents, it can be concluded that consumers' preference in choosing a place for taking their English course in Bandung, is based on their teaching method where the faculty members (teachers) have the utility's value of 0.051 . This indicate that high school students in Bandung prefer experts as their teachers in comparison to foreigners.

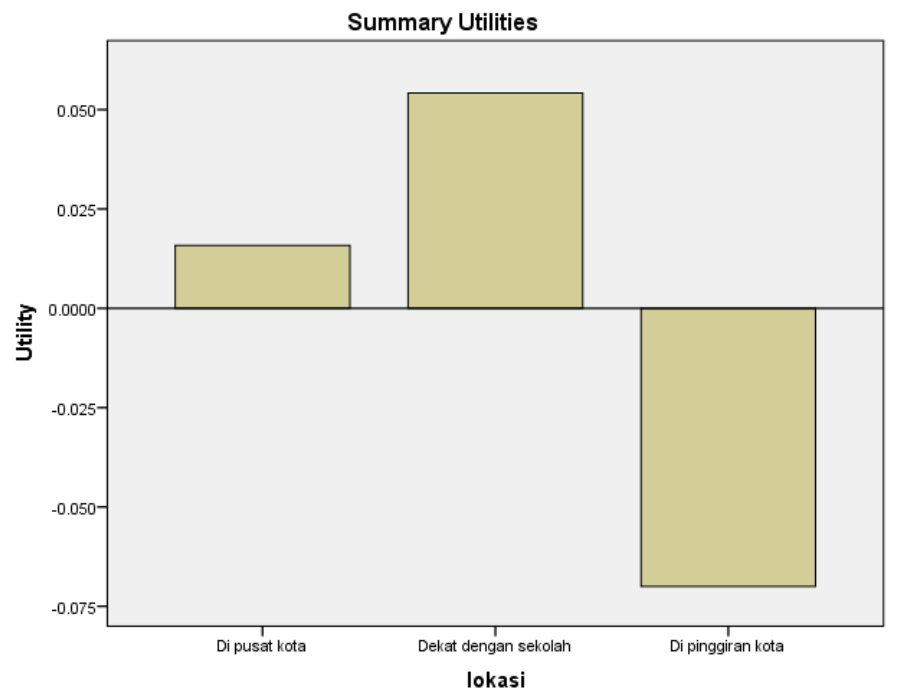

Picture 4: The Value of Location's Attribute Utility

From the picture above it can be seen that the value of the level attribute for utility location is 0.016 for downtown, 0054 for location close to schools, and for suburbs its utility value is -0.070 .

Based on the description above, it can be concluded that the 100 respondents prefer courses that are located near the school compared to the course which is located in downtown or in the suburb.

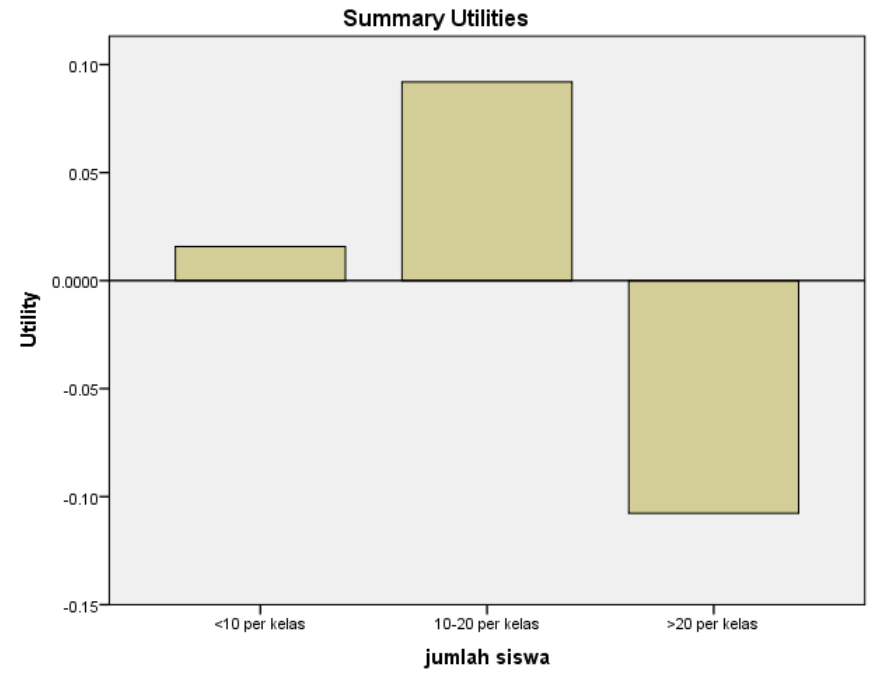

Picture 5: The Value of Number of Students' Attribute Utility 
From the picture above, it can be noted that the utility value of number of students is 0.016 for the total students < 10 people per class, 0.092 for number of students of 10-20 persons per class, and -0.108 for the number of students $>20$ people per class.

Based on the description above, it can be concluded that high-school students prefer a 'not too crowded' classroom or 'too empty' when the number of students is around 10-20 people per classroom. This is evident based on the utility value of 10-20 students per class is greater than the value of the utility's total students $<10$ people per class, and $>20$ people per class.

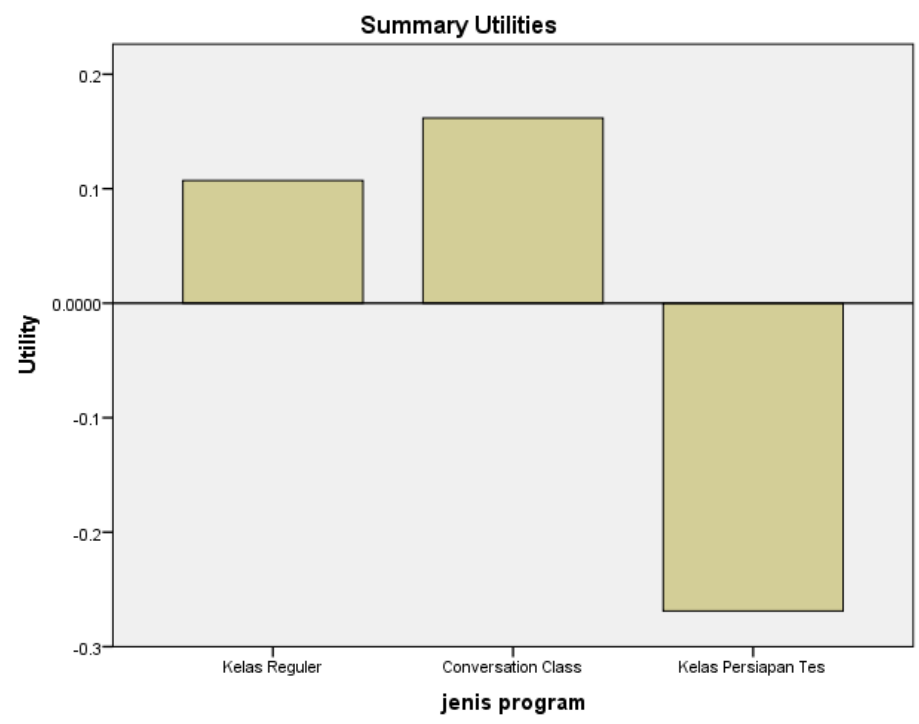

Picture 6: The Value of Types of Program's Attribute Utility

From the picture above it can be seen that the utility value of types of program in regular classes is 0.107 , in conversation classes is 0.162 , and for preparation-test classes is -0.269 . Based on that description, it can be concluded that high-school students prefer conversation class program compare to the regular class program and/or the test preparation classes.

\subsection{THE ANALYSIS OF IMPORTANCE VALUE BETWEEN VARIABLES}

The Importance Value is the appeal or weight that determine which attribute is the most important. In other words, it tells us which attribute that affect consumers the most, when they want to choose the English Course in Bandung. The Importance Value is calculated through SPSS until it has the highest number wherein the total number of a combine attribute is $100 \%$. 


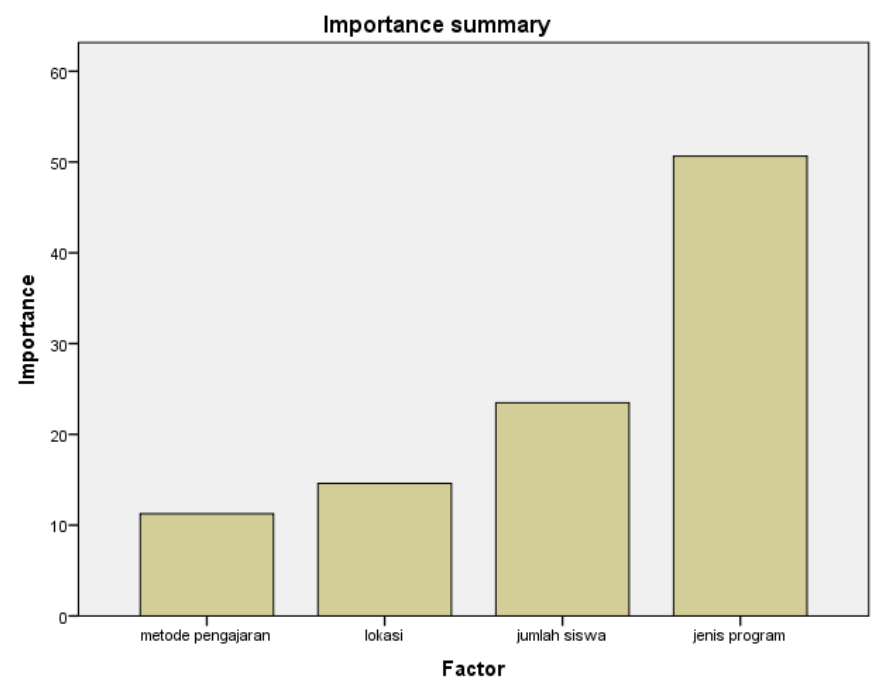

Picture 7: The Value of Interests between Variables

Based on the picture above, it shows that the attribute that affect consumers' preference in choosing an English Course in Bandung is the types of program that it provides. That can be proven by looking at the result from questionnaires' data which is 50,649. The second highest attribute is the total number of student in the classroom which is 23,487 . The third highest attribute is the location which is 14,608 and lastly, the attribute that affect the consumers is the teaching method as high as 11,256 .

\section{CONCLUSION AND SUGGESTIONS}

\subsection{CONCLUSION}

Based on the results conducted through its 100 respondents - consisting of high-school students learning English in Bandung, they are as the following:

1) The Conjoint's analysis indicates that high-school students prefer to study English in a conversation class that has10-20 students in the classroom, where its location is near school and its teaching method uses experts.

2) Based on the Conjoint's analysis, the most important factors of that high-school students consider in choosing an English course is the type of program that it offers, the total students in the classroom, the location and the teaching method.

\subsection{SUGGESTIONS}

\section{FOR COMPANIES}

a) The prominent factor that affect consumers' satisfaction is the type of program that the English course offers. Thus, the authors advice for companies to give a more importance toward conversation class program for high-school students, in Bandung.

b) The number of students per classroom needs to be noted because it high-school students like to have 10-20 students in a classroom. 
c) The location in which the English Course is located needs to be near schools so high-school students can easily reach it. It is interesting that they dislike English Course which is located in the centre of town or suburb. Thus, it is best if the location is near their schools.

d) Lastly, it is important to pay attention to the teaching method where experts are the ones who are teaching because high-school students like better if their teachers are experts instead of 'native' only.

\section{FOR FURTHER RESEARCH}

a) It is advised that further research need to be done on the relation between English Courses with the students' interest to learn, for example.

b) To expand the scope of research to junior high school or elementary students, as well as undergraduate students in order to understand their preference in choosing the right place in learning English.

\section{REFRENCES}

[1] Abdullah, Thamrin dan Tantri Francis. (2012). Manajemen Pemasaran. (1). Depok : PT Raja Grafindo Persada.

[2] Dantes, Nyoman. (2012). Metode Penelitian. Yogyakarta : C.V Andi Offset.

[3] Darmawan, Deni. (2013). Metode Penelitian Kuantitatif. (1). Bandung : PT Remaja Rosdakarya.

[4] Elbert, Ronald J. ; Griffin, Ricky W. (2009). Business. New Jersey: Prentice - Hall

[5] Ef.co.id. (2015). Beragam Kursus Bahasa Inggris di EF. Didapat dari : http://www.ef.co.id/englishfirst/default.aspx

[6] Gaspersz, Vincent. (2011). Ekonomi Manajerial. Jakarta : PT Niaga Swadaya.

[7] Hair, J.F., et al. (2010). Multivariate data analysis. (7th edition). New Jersey : Pearson Education Inc.

[8] Hartono, Jogiyanto. (2012). Metodologi Penelitian Bisnis. (1). Yogyakarta : BPFE.

[9] Infokursus.net. (2015). Rekap Jumlah Jenis Kursus. Didapat dari : http://www.infokursus.net/sie/rekap-jenkur.php?prop $=02 \& x=23 \& y=12$

[10] Ilp.co.id. (2015). Programs. Didapat dari : http://www.ilp.co.id/

[11] Kolawole, C. O. (1998). Linguistic Inputs and Three Models of Presentation as Determinants of Students' Achievement in Senior Schools Easy Writing. Unpublished. Ph.D. Dissertations, University of Ibadan.

[12] Kotler, Philip; Kevin, Lane Keller. (2009). Manajemen Pemasaran edisi 12 jilid 1. Jakarta : Erlangga.

[13] Kotler, Philip; Kevin, Lane Keller. (2009). Manajemen Pemasaran edisi 12 jilid 2. Jakarta : Erlangga.

[14] Kotler, Philip; Kevin, Lane Keller. (2009). Manajemen Pemasaran edisi 13 jilid 1. Jakarta : Erlangga.

[15] Lia.co.id. (2015). Program Belajar Bahasa Inggris. Didapat dari : http://lia.co.id/index.php/program-belajar/bahasa-inggris.html

[16] Lupiyoadi, Rambat. (2013). Manajemen Pemasaran Jasa. Jakarta : Salemba Empat.

[17] Moogan, Yvonne J; Baron, Steve; Bainbridge, Steve. (2001). Timings and trade-offs in the marketing of higher education courses: a conjoint approach. 19(3), 179-187. Marketing Intelligence and Planning Journal. 
[18] Mothersbough, David; Hawkins, Delbert. (2010). Consumer Behavior, Building Marketing Strategy: Eleventh Edition, Mc.Graw.Hill International Edition

[19] Nitisusastro, Mulyadi. (2012). Perilaku Konsumen dalam Perspektif Kewirausahaan. (1). Bandung : Alfabeta.

[20] Peter, Paul J; Olson, Jerry C. (2013). Perilaku Konsumen \& Strategi Pemasaran. Edisi Sembilan. Jakarta : Salemba Empat.

[21] Sanusi, Anwar. (2011). Metodologi Penelitian Bisnis. Jakarta : Salemba Empat.

[22] Schneider, W, Edgar. (2003). English Around the World. United States : O"Reilly Media.

[23] Supranto, J. (2010). Analisis Multivariat Arti \& Interpretasi. (2). Jakarta : PT.Rineka Cipta.

[24] Tbi.co.id. (2015). Kursus-kursus Kami. Didapat dari : http://www.tbi.co.id/id/kursuskursus-kami

[25] Tjiptono, Fandy. (2011). Pemasaran Jasa. Malang : Bayumedia.

[26] Umar, Husein. (2013). Metode Penelitian untuk Skripsi dan Tesis Bisnis. Jakarta : Rajagrafindo Persada.

[27] Zikmund, William. (2010). Business Research Method (8th Ed.). Canada : Cengange Learning. 